Poster Abstracts

\title{
CALCIUM FERTILISATION REDUCES INCIDENCE OF SOFT ROT (ERWINIA CAROTOVORA) ON POTATO TUBERS
}

\author{
P.J. WRIGHT and C.M. TRIGGS ${ }^{1}$
}

\begin{abstract}
New Zealand Institute for Crop \& Food Research Limited, Cronin Rd, RD1,Pukekohe,
\end{abstract}
${ }^{1}$ Dept of Statistics, University of Auckland, Private Bag 92019, Auckland, New Zealand

The concentrations of calcium (Ca) in both tuber skin (periderm) and medullar tissue of potatoes (cv. Rua) grown at Pukekohe on a clay loam were increased by applications of calcium fertiliser before tillage, at planting and as side dressings. Tubers from plots that received a pre-tillage broadcast application of 5 tonnes/ha gypsum $\left(\mathrm{CaSO}_{4}\right)$ had higher calcium levels than tubers that received $500 \mathrm{~g} / \mathrm{ha}$ gypsum applied as a band at planting and/or a side-dressing of $645 \mathrm{~kg} / \mathrm{ha} \mathrm{Ca}\left(\mathrm{NO}_{3}\right)_{2}$ at tuberisation. Tubers that were given no calcium fertiliser had the lowest concentrations of calcium in the skin $(640 \mathrm{ppm})$ and medullar tissue (266 ppm), whereas the highest skin calcium concentration (1083 ppm) was achieved by application of calcium at pretillage plus at planting. The highest medullar calcium concentration (334 ppm) was achieved by applying calcium on all three occasions. When tubers were inoculated with Erwinia carotovora subsp. atroseptica (Eca) and incubated for 6 days at $20^{\circ} \mathrm{C}$ in moist chambers, tubers from plots that were not supplied with calcium had more rot $(16.6 \mathrm{~g})$ than tubers from plots that had calcium applied pre-tillage and at tuberisation (9.2 and $9.3 \mathrm{~g}$ rot). The relationship between the amount of soft rot and tuber skin calcium was not linear. The addition of calcium did not affect total yield or grade of tubers.

\section{SOIL SOLARISATION AS A CONTROL METHOD FOR ONION WHITE ROT}

\author{
K.L. McLEAN and A. STEWART \\ Department of Plant Science, Lincoln University, P.O. Box 84, Canterbury, N.Z.
}

Sclerotium cepivorum Berk. sclerotial viability was greatly reduced when sclerotia were incubated in soil at temperatures ranging from 20 to $50+^{\circ} \mathrm{C}$. Temperatures above $40^{\circ} \mathrm{C}$ reduced sclerotial viability to $0 \%$ after a 1 day exposure period, whereas at $20^{\circ} \mathrm{C}$, sclerotial viability was reduced to $10.7 \%$ after 28 days. Temperatures greater than $20-25^{\circ} \mathrm{C}$ adversely affected sclerotial viability. Sclerotial degradation was greatest with short periods of high temperatures rather than long periods of low temperature. A four week soil solarisation trial was set up using artificially produced $S$. cepivorum sclerotia buried in the soil at 10 and $20 \mathrm{~cm}$ depths under polythene. While there was a significant difference in the maximum and minimum temperatures recorded at 10 and $20 \mathrm{~cm}$ in both the solarised and non solarised soil, the increase in temperature at the shallower depths did not affect sclerotial viability. The sclerotia recovered from the solarised plots were colonised by a number of fungal species. These included: species of Verticillium, Penicillium, Fusarium, Trichoderma and an isolate of Paecilomyces lilacinus. Future studies will investigate the application of temperature tolerant antagonistic microorganisms with the soil solarisation treatment to enhance sclerotial degradation and reduce sclerotial numbers in the soil. 